\title{
The Views of NU Ulama in Medan about Polygamy
}

\section{Edi Sahputra Siregar}

Sekolah Tinggi Islam Negeri Maindailing Natal, Indonesia

edisahputrasiregar145@gmail.com

\begin{abstract}
This study uses a perspective that uses a combination of theories polygamy normative scientific perspective, the opinion of the scholars and the phenomenon of reality as viewed by scholars $N U$ in Medan. Generally found that the views of the scholars NU Medan on polygamy is something that is permissible on the ba sis of the text of the Quranic verse of Surat an-Nisa', paragraph 3 which makes the fair as an essential prerequisite skill, because polygamy is a kemslahatan and also a solution to solve the problem, sehinggah polygamy is allowed to be done but it must first be discussed with the family without needing any government intervention to deal with it, because they consider the legislation only complicates something that has obviously legal skill in the Qur'an.
\end{abstract}

Keywords view; NU ulama; polygamy

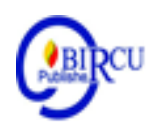

\section{Introduction}

Marriage is the process by which two people make their relationship public, official, and permanent. It is the joining of two people in a bond that putatively lasts until death, but in practice is increasingly cut short by divorce. Over the course of a relationship that can last as many as seven or eight decades, a lot happens. Personalities change, bodies age, and romantic love waxes and wanes. And no marriage is free of conflict (Jamaluddin, 2018).

Islam basically allows a man to have more than one wife (polygamy). Islam allows a man to have up to four wives on the condition that the husband must be able to do justice to all his wives. Allah says in Surah An-Nisa '(4) verse 3:

Meaning: and if you are afraid that you will not be able to do justice to (the rights) of an orphaned woman (if you marry her), then marry the (other) women that you like: two, three or four. Then if you are afraid that you will not be able to be fair, then (marry) only one person, or the slaves you have. So it is closer to not persecuting. "(QS. An-Nisa '(4): 3).

The clerical debate over the issue of polygamous marriage has existed for a long time. Among them are those who allow and some are prohibited. This is closely related to the interpretation of the verses of the Koran regarding fair conditions and the boundaries of the wife who wants to marry. If we examine the interpretations of modern scholars, who have begun to pay attention to aspects of women's interests, and avoid interpreting gender bias, we find that they are more moderate and pay attention to women. When the time of Islam came, men already had ten wives, less, or more than that, without restrictions and conditions. Islam then gave limits that could not be violated, namely four and there were also conditions, namely that they must be able to do justice, if not. Can, then monogamy is absolute and must not exceed it.

Despite this controversy, polygamy still occurs in society. Is this the impact of social change that is so fast that it causes a shift in value and then affects every individual action or maybe it is also due to weakening social control in society? Social control is always needed in a society to achieve harmony between stability and changes in society. Social control has a very broad meaning, not only public supervision of the government, but also individual social 
control over other individuals. All of these are social control processes that can occur in everyday life, even though people are often not aware of it.

Many factors cause a person to deviate or deviation. One of them is because of weakening social control or because of a shift in values which then causes a change in the way a person perceives the existing norms in society. In this case, people who are polygamous have a different perspective or mindset from society in general regarding religious norms or other norms related to the issue of polygamy. There are several factors that may influence a person's mindset or perspective, including educational, socio-cultural and economic factors.

In general, it can be said that the problem of polygamy is normatively directly related to Q.S. An-Nisa ': 3.This verse specifically talks about the permissibility of marrying more than one, but on the other hand it can also be understood as a prohibition to marry more than one because in the end this verse mentions conditions that are difficult to meet someone who wants to marry more than one. It can be understood that the ambiguity of the verse implicitly shows the possibility of multiple meanings in understanding the verse.

The indecisiveness of this verse is the cause of differences among scholars in understanding polygamy, including those who accept or reject polygamy as well as specifically related to the verse mentioned because this verse relating to the issue of polygamy only mentions the possibility that the uncertainty that accepts and rejects can be justified based on that verse. Based on this verse, it can be understood that the debate on polygamy is something commonplace and certainly on the other hand is something that is open to existing choices regarding views on the problem of polygamy.

The polygamy debate was explicitly stated by Untung Yugono:

"The arguments justifying the practice of polygamy are mainly put forward on the basis of textual references, namely what is written in the holy book al-Qur'an and the Sunnah of the Prophet having more than one wife. Surah An-Nisa 'verse 3 is a reference in the Koran which clearly allows a man to take more than one wife, while the Prophet Muhammad has more than one wife with one of the goals of liberating slaves (lifting the dignity of the poor), and that is what pro polygamy groups use in justifying the practice of polygamy. This argument was opposed by anti-polygamists with views of the same reference, but with different points of view. According to anti-polygamists, including Islamic feminists, the Koran, including the verses in it that allow polygamy and the Prophet's Sunnah, need to be interpreted in a contextual, reconstructive way and living according to the Koran and the Prophet's Sunnah are essential views in the discourse of renewal and liberalization Islam."

Based on the debate stated, it is clear that the pros and cons of polygamy both have a strong normative basis. For this reason, this paper is not intended to justify differences in understanding the arguments related to the problem of polygamy. Apart from that, of course it is interesting to see further how the NU ulama's view of polygamy as a part that includes pro-polygamy and practices polygamy a lot. However, of course some of the other NU ulama firmly reject polygamy for various reasons put forward.

It is interesting to point out here, the practice of polygamy, especially among those who are pro-polygamy, is mostly practiced by religious leaders or ulama, especially those who are involved in traditional religious organizations such as NU. The practice of polygamy carried out by NU ulama is of course closely related to the view of the NU Ulama which states that polygamy is something that is justified in Islamic law, so recording at the KUA does not become a legal requirement for marriage and a wife's permission for polygamy is not required. 
For this reason, of course it is interesting to carry out further research related to the practice of polygamy, especially the views of polygamy actors on women's rights. The view of NU ulama in Medan on polygamy is intended to be known more fully because how actually the rights of women in a polygamous family are interesting. This is because the NU ulama's view on polygamy is fully related to the background and basic views put forward by the NU ulama about polygamy itself.

This fact of course has implications for the non-uniformity in understanding polygamy. Therefore, according to the author, it is certainly relevant to conduct a more intensive study of the Views of the Ulama Nu Kota Medan about polygamy.

\section{Review of Literatures}

\subsection{Definition of Polygamy}

Etymologically, the term polygamy comes from the Greek word apolus which means many and gamos which means marriage. Polygamy in Arabic terms: الزوجة تعدد which means the act of a man collecting in his responsibilities two to four wives, no more than him.

Meanwhile, in the Big Indonesian Dictionary, polygamy is a marital bond in which one party has / marries several opposite sexes at the same time. The word can include polygyny, namely "a system of marriage that allows a man to marry several women at the same time", or vice versa, namely polyandry, in which a woman has / marries multiple men.

According to Sudarsono, when a man marries two to four people it is called polygamy. With the following characteristics: (1) Those who marry more than one are only on the side of the man, therefore treatment that deviates from these characteristics is prohibited by Islam; (2) The number is limited, namely a maximum of four women according to the letter al-Nisa verse: 3 ; (3) Every polygamy must meet certain conditions, namely that men can do justice to their wives, have a turn to have sex and provide for a living.

In Islam, polygamy means more than one marriage, with the general limit being only up to four women. Although there are also those who understand the verse about polygamy with a limit of four or even more than nine wives.

In short, polygamy is a marriage bond in which one party (husband) marries several (more than one) wives at the same time. Men who enter into this form of marriage are said to be polygamous.

Polygamy or having more than one wife is not a new problem, it has existed in human life since time immemorial among various groups of people in various regions of the world. However, in Islam, polygamy means more than one marriage with restrictions, generally only up to four women are allowed. Although there are also those who understand the verse about polygamy with a limit of more than four or even more than nine wives. This difference is caused in understanding and interpreting verse 3 of Surah An-Nisa ', as the basis for establishing the law of polygamy. In other words, polygamy is practicing more than one wife, namely two, three or four. This is also stated in Article 55 Paragraph (1) of the KHI that "has more than one wife at the same time, limited to only four wives". The provisions of Law Number 1 Year 1974, both article by article and explanation, do not find the meaning of polygamy. Only Article 3 paragraph (2) of Law Number 1 Year 1974 states that "The court can give permission for a husband to have more than one wife if the parties want to."

People who are Muslim so far, according to Islamic law, are allowed to have two, three and four wives, after the enactment of Law No.1 of 1974 it has become increasingly difficult, because the government has intervened in determining the desire of a husband who wants to marry a woman as the second, third, or fourth wife. A husband who wants to marry a widowed woman on the basis of humanitarian considerations, namely because he feels sorry 
for a widow's child who has no father anymore, cannot be used as an excuse to marry a second time, for reasons of humanitarian considerations so called cannot be accepted by law. Law Number 1 of 1974 concerning Marriage.

The reasons that can be used as a basis for a husband to practice polygamy have been determined by law (Law Number 1 of 1974) in a limited manner, namely: (1) The wife cannot carry out her obligations as a wife. (2) The wife has a disability or an incurable disease. (3) The wife cannot give birth to offspring.

The court will not give permission to a husband who applies for remarriage or to obtain a second, third or fourth wife if the reasons submitted are not in accordance with what is stated in Article 4 paragraph (2) of Law No.1 of 1974.

In addition to the reasons stated in Law Number 1 Year 1974, other requirements are still needed, as contained in the explanation of Article 3 paragraph (2) of Law Number 1 Year 1974 which states: "The court in giving decisions other than examining whether the requirements mentioned in Articles 4 and 5 have been fulfilled. "

In Islamic law, polygamy is justified on the condition that it can be treated fairly between wives, in order to protect women as mothers and to avoid adultery not only for the benefit of men, but also for the benefit of women and society.

\subsection{Opinion of Ulama against Polygamy}

The scholars differed about the law of polygamy. Masjfuk Zuhdi explained that Islam views polygamy as carrying more risks or harm than benefits. Because humans according to their nature are jealous, jealous and like to complain. These characteristics easily arise in a high degree if you live in a polygamous family life. Polygamy can be a source of conflict in family life, both conflicts between husbands and wives and children of their wives, as well as conflicts between wives and their respective children. Therefore, the law of origin of marriage in Islam is monogamy, because with monogamy it is easy to neutralize jealousy, jealousy and complaining in a monogamous family. Unlike the polygamous family life, people will be easily sensitive and aroused by feelings of jealousy, envy, envy and complaining in high levels, so that it can disturb the peace of the family and can endanger the integrity of the family. Thus, polygamy is only allowed, if in an emergency, for example, the wife is infertile (unable to produce offspring), the wife is affected by a disease that causes her to not fulfill her obligations as a wife.

The priests of the mazhab also gave advice, if you cannot do justice, it is better to have one wife alone. Sunnah expert scholars have also agreed that if a husband has more than four wives then the law is haram. The fifth marriage and so on are considered null and void, unless the husband has divorced one of the four wives and his iddah period has also ended. In the matter of limiting wives to four people, Imam Syafi'i argues that this has been shown by the Sunnah of the Prophet Muhammad, as an explanation of the word of Allah SWT, that apart from the Messenger of Allah no one is allowed to marry more than four women.

\section{Research Method}

This research is a field research, where all data is obtained from the field. In this approach method, research is carried out in natural situations but is preceded by some kind of intervention (intervention) on the part of the researcher. This intervention is intended so that the phenomena desired by the researcher can be immediately seen and observed. Thus there is a kind of control or partial control of the situation in the field.

The data collection method is used in such a way as to obtain truths that can be used to answer the problems raised in the research. The method of data analysis in accordance with 
this research is to use the descriptive analysis method with the aim of knowing systematically, factually, and accurately about the facts and characteristics of the population describing phenomena in a particular field or area.

\section{IV.Discussion}

\subsection{The Views of NU Ulama in Medan about Polygamy}

The phenomenon of polygamy (polygyny) is not something new in the realm of Islam. The majority of Indonesian people adhere to Islam, making polygamy a discourse that continues to be debated from time to time. In fact, the discourse on polygamy in Indonesia since the issuance of PP. 10 of 1983 as the realization of Law no. 1 of 1974 concerning marriage has created restrictions on Indonesian citizens. The polygamy discourse then entered the political realm. In practice, polygamy is like the hijab practice with cultural, social and even economic nuances. The problem of polygamy is therefore not only a theological problem, but it is full of non theological contents.

Thus, in practice, polygamy also deals with non-theological aspects, so its construction in every place will have a dialogue with cultural, social, and even economic elements. Therefore, a socio-cultural, socio-economic, political, as well as geographic and historical approach is needed in photographing the reality and perception of polygamy in a society. If theological studies debate the pros and cons of polygamy, non-theological studies attempt to construct how the discourse on polygamy is formed in a community related to cultural, social, economic, and even political elements.

Some of the society doesn't agree with polygamy and they oppose the practice of polygamy that exists today, because the negative effect is very big for the family and hurts a lot of women. However, some others agree with polygamy for certain reasons. This last group argues that although polygamy has many risks, it is not something that is prohibited by Islamic shariah, as is the view of the ulama of Medan city NU. Based on interviews with several NU scholars in Medan about their views on polygamy. In general, it is said that polygamy is allowed to be carried out for certain reasons, as expressed by Mr. M. Abror Daud Faza Batubara, the administrator of NU in Medan:

"Islam has made polygamy a permissible act, not sunnah, nor mandatory. The basis for the permissibility of polygamy is because Allah SWT has explained very clearly about this in Q.S an-Nisa: "Then marry you (other) women whom you like two, three or four." Sababun nuzul this verse, that Urwah bin Zubair asked Ayesha about the verse of QS An-Nisaa': 3. Then Ayesha replied, "O my sister's child, orphaned here means a girl who is under the care of her guardian whose wealth is mixed with her guardian property. And the wealth and beauty of the orphan makes the caregiver of the orphan happy with him and then wants to make the orphan woman his wife. Orphans like this are prohibited from marrying the orphans unless they want to be fair to them and give them a higher dowry than usual. And if they cannot do this, then they are ordered to marry other women who they like. "(Al-Bukhari) However, the permissibility of polygamy in the above verse does not always have to be related to the context of caring for orphans, as some people argue. Because as it has been understood in the science of ushul fiqih, what is used as a reference (al- ibrah) is the editorial sound of a general verse (fankihuu maa thaab lakum mina an-nisaa etc.), it is not the reason for the decline of specific verses (the care of orphans. So polygamy can be practiced both by those who care for orphans and those who do not care for orphans. Polygamy is allowed by referring to the verses / texts of the Koran, and polygamy that is carried out must be in accordance with the provisions of the Shari'ah, and the husband it must be able to act fairly and fairly, it doesn't have to be the same. 
The same thing was also expressed by Ngatman Azis M.Pd, the NU figure in Medan:

"Polygamy is allowed but not an obligation. Polygamy can be done in any condition, as long as there is the consent of the first wife beforehand, and both parties are sincere to do polygamy, and most importantly, it must be fair in treating the two wives, although the fair measure depends on the ability, both in fairness and respect. material matters or fair in terms of affection. If you look at the zahir verse about polygamy, the use of the command form "fankihuu" which means "then marry" means that Allah swt uses the command sentence (amr). Where in the rule of ushul fiqh it is explained, "the form of an order indicates obligatory" (shighatu fi'li-amr tadullu alal wujub), it means that the verse requires an obligation. Obviously, the determination of the "obligatory law" of the verse will occur if someone does not know the principles of ushul fiqh science and only looks at the above verse in fragments, without paying attention to the previous verse fragments. Whereas if you pay attention to the previous verse in the form of prohibition of marrying orphaned women and for fear of not being able to do justice to them, then Allah swt - in the same verse - orders to marry a second, third or fourth woman, this is will be a question mark for some people. In fact, the answer is clear, based on the rules of ushul fiqh, if an order comes after the prohibition it will give meaning and show the law "may" (Jaiz), not obligatory or haram.

In the case of polygamy, as stated by the respondents above, the main condition for practicing polygamy is fair. Justice is a central teaching in Islam and is universal. This universal character can be seen from the existence of humans wherever and whenever they yearn for justice. In humans, there is spiritual potential that whispers feelings of justice as something that is right and must be upheld. Deviations against justice tarnish the essence of humanity. Therefore, Islam with the main mission of rahmatan li al-'alamin, the bearer of mercy for all nature, places justice as something fundamental.

Al-Qur'an as the holy book of Muslims shows the practice of upholding justice, respecting and uplifting those who do justice, and prohibiting and denouncing acts of injustice. Al-Qur'an also places justice as a principle that must be upheld by every human being in all his life activities. Fairness is the closest virtue to piety because justice is a reflection of piety. This can be seen in the word of Allah Surah Al-Maidah verse 8:

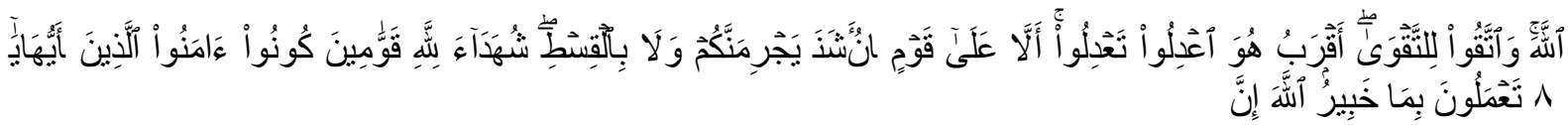

Meaning: "O you who believe, let you be the ones who always uphold (the truth) for Allah's sake, be witnesses fairly and do not let your hatred of a people encourage you to be unjust. Be fair, because fair is closer to piety and fear Allah, Allah knows best what you are doing. "(Surah Al-Maidah (5): 8).

Likewise with polygamy, the conditions for a polygamous husband must be fair to his wives. With regard to the condition of being fair, this is often a long debate not only among legal experts but also in the community. Therefore, the meaning of justice becomes a fundamental question in the context of polygamy. Imam Syafi'i, as-Sarakhsi and al-Kasani require justice between wives, according to them this justice only concerns physical matters such as visiting wives at night or during the day. According to the scholars of fiqh, a husband who wants to do polygamy has at least two conditions: First, the ability to have sufficient funds to finance various needs by increasing his wife. Second, must treat all wives fairly. Every wife must be treated equally in fulfilling her marital rights and other rights.

However, there are also respondents who say that polygamy is maslahat and still in accordance with contemporary conditions today, as stated by $\mathrm{H}$. Achyar Nst, L, and c:

"Even though only one verse is the basis for the permissibility of polygamy in the Koran, polygamy is allowed to be practiced and until now the concept offered by the 
Koran regarding polygamy remains relevant and appropriate for the present time, but more so. First discussed in depth between husband and wife and then conveyed and understood to the family, because polygamy is actually a benefit, polygamy is better than being trapped in adultery".

The NU Ulama in Medan, in viewing the polygamy problem, according to observations made generally only rely on the text of the verse without needing to be actualized with current conditions, but there are also some who have different opinions who express objections about polygamy and state the arrangement of polygamy for the current context, must comply with the prevailing laws and regulations.

From the beginning, Islam was believed to be a pious teaching, li kulli zaman wa makan; that Islam is a universal religion and the applicability of its teachings goes beyond the boundaries of time and space in human history. The claim of universality demands that Islam be able to answer the challenges of life that are always changing along with changing times and the socio-cultural context where the last religion stands. At this time, fiqh as a legal product which is deduced from the main sources of Islam (al-Qur'an and hadith) and serves as a guide for Muslims in living their practical lives is the most important aspect of Islam which must answer these challenges, especially in matters of family law.

\section{Conclusion}

Based on the description of the discussion that has been described, the authors conclude as follows:

Polygamy according to the view of the Medan City NU Ulama is something that is permissible based on the text of the verses of the Koran surah An-Nisa 'verse 3 which makes fairness the main prerequisite for its ability, because polygamy is a benefit and also a solution to solve problems, so polygamy is permissible. to do so, but first it must be discussed with the family without the need for government intervention to take care of this, because they think that laws and regulations only complicate things that have clear legal permissibility in the Koran. However, there are also some Medan City NU Ulama who object to polygamy which is understood only in accordance with the text of the Koran without seeing the condition of the feeling of the wife who wants to be polygamous. Polygamy that is suitable for now is polygamy in accordance with the rules required by law which can only be done according to the right reasons.

The background to the view of the Medan City NU Ulama is the understanding of the text of the Koran, namely in Surah An-Nisa 'verse 3 which states the ability of polygamy, because according to their view that the text of the Koran is something that cannot be contested or reinterpreted, because the text of the Koran is a fixed price that does not accept change, then polygamy is a solution to solve family problems such as an infertile or sick wife who is ultimately unable to carry out her obligations as a wife, and polygamy is a benefit offered by Islam which is permissible to do as long as it is done not because of lust.

According to the laws and regulations, polygamy is different from the views of the Medan City NU Ulama, according to them the terms of polygamy are too loose and without government interference, however according to the laws and regulations polygamy can be done after obtaining permission from the court in accordance with Article 3 paragraph 2 of the Law No. 1 of 1974 concerning Marriage, as well as Article 4 and in the Compilation of Islamic Law Articles 55-59 which states that the main requirement for a husband to have more than one wife is to be able to be fair to his wives and children. As for the conditions stipulated by the Religious Court: 1) The wife cannot carry out her obligations as a wife; 2) The wife has a physical disability or incurable disease; 3) The wife cannot give birth to 
offspring. Polygamy can only be done properly under urgent circumstances, therefore marriage adheres to the principle of open monogamy.

\section{References}

Arikunto,Suharsimi. (1998). Prosedur Penelitian, Jakarta: Rineka Cipta.

Asghar Ali Engineer. (1994). Hak-hak Perempuan dalam Islam, terj. Farid Wajidi dan Assegaf, Cici Farkha, Yogyakarta: LSPPA \& CUSO.

Azwar, Saifuddin. (1998). Metode Penelitian, Yogyakarta: Pustaka Pelajar Offset.

Bahri, S., and Batoebara, M.U. (2020). The Position and Participation of Khadijah in Developing Da'wah in Islam at the First Period. Budapest International Research and Critics Institute-Journal (BIRCI-Journal) Volume 3, No 1, February 2020, Page: 287295.

Departemen Agama, al-Qur'an dan Terjemahnya, Jakarta :PT Bumi Restu, 1976-1977, Q.S Al-Maidah (5) : 8).

Departemen Pendidikan dan Kebudayaan. (1993). Kamus Besar Bahasa Indonesia, Jakarta: Balai Pustaka.

Djannah, F., and Rizal, M. (2019). The Role of Saving and Lending Cooperatives in Increasing Its Members Earning and Review Based On Islamic Law. Budapest International Research and Critics Institute-Journal (BIRCI-Journal) Vol 2 (4): 616623.

Do'i , Abdul Rahman I. (2002). Penjelasan Lengkap Hukum-Hukum Allah (Syari'ah), Jakarta; Rajawali Press.

Hadikusuma,Hilman. (1990). Hukum Perkawinan Indonesia Menurut Perundang-undangan Hukum adat, Hukum Agama, Bandung: Mandarmaju.

Hafifuddin, Didin. (2003). Memahami Keadilan dalam Poligami, Jakarta: Globalmedia.

Halimatussa'diah. (2020). Values of Da'wah in Aceh Tradition (Case Study of Lueng Keubeu Samalanga Village). Britain International of Humanities and Social Sciences (BIoHS) Journal, 2(1), 72-81.

Haries, Akhmad, Poligami dalam Perspektif Asghar Ali Engineer dan Relevansinya dengan Konteks Indonesia (makalah di Jurusan Syari'ah STAIN Samarinda, tidak diterbitkan).

Hosen, Ibrahim. (1995). "Beberapa Catatan tentang Reaktualisasi Hukum Islam", dalam Muhammad Wahyuni Nafis dkk (ed), Reaktualisasi Hukum Islam: 70 Tahun Prof Dr Munawir Sjadzali, MA, Jakarta: Paramadina \& IPHI.

Ismail. (2003). Nurjannah, Perempuan dalam pasangan: Bias Laki-laki dalam Penafsiran Yogyakarta: LKiS.

Jamaluddin. (2018). AL Ghazali's View Regarding to the Witness in Islamic Wedding Ceremony. Budapest International Research and Critics Institute-Journal (BIRCIJournal). P.01-10

Kansil, C.S.T.(1999). Pengantar Ilmu dan Tata Hukum Indonesia, Jakarta : PN. Balai Pustaka.

Kau, Sofyan AP \& Kau, Mubasyir P. (2008). Fikih Alternatif,Gorontalo: Sultan Amai Press.

Koentjaraningrat. (1977). Metode-Metode Penelitian Masyarakat, Jakarta: Gramedia Pustaka Utama.

Nasution Khoiruddin. (1996). Riba Dan Poligami: Sebuah Studi Atas Pemikiran Muhammad Abduh, Yogyakarta: Pustaka Pelajar bekerjasama dengan ACADEMIA.

Nasution, Khoiruddin. (2002). "Perdebatan sekitar Status Poligami”, Jurnal Musawa, No. 1. Vol. 1. Maret. 
Nasution, Khoiruddin. (1996). Riba \& Poligami: Sebuah Studi atas Pemikiran Muhammad Abduh, Yogyakarta: Pustaka Pelajar.

Nurohmah, Leli. (2003). Poligami Saatnya Melihat Realitas, Jakarta: Jurnal Perempuan : Untuk Pencerahan dan Kesetaraan, Edisi 31.

Qurtubi Muhammad. (1993). Jami' li Ahkam al-Qur'an, Bairut: Dar al-Kutub al-'Ilmiyah.

Qutb,Sayyid.( 2001).Tafsir fi Zhilal al-Qur'an, Jakarta: Rabbani Press.

Rahman, Abdul I Doi. (1992). Perkawinan Dalam Syariat Islam, Jakarta: Rineka Cipta.

Ridho, Rasyid, Tafsir al-Manar, Mesir; Dar al-Manar, th.

Selamat, Kasmuri. (1998). Pedoman Mengayuh Bahtera Rumah Tangga, Jakarta: Kalam Mulia.

Shahrur, Muhammad, Nazhariyatul Hudud. (2004). (Terj. Sahiron Syamsuddin dan Burhanuddin), Metodologi Fiqih Islam Kontemporer, Yogyakarta: eLSAQ.

Soekanto Soerjono. (1990). Sosiologi Suatu Pengantar, cet. Ke-4, Jakarta: Rajawali Pers.

Sudarsono. (1992). Pokok-pokok Hukum Islam , Jakarta: Rineka Cipta.

Sumadi, Suryabrata. (1995). Metodologi Penelitian, Jakarta: Raja Grafindo Persada.

Syahrur, Muhammad. (2010).Nahw Ushul Jadidiah lil Fiqh al Islami diterjemahkan oleh Sahiron Syamsuddin dan Burhanuddin dalam Metodologi Fiqh Islam Kontemporer, cet VI, Yogyakarta: Elsaq Press.

Yugono, Untung. (2008). "Ketika Perempuan Lantang Menetang Poligami: Sebuah Analisis Wacana Kritis tentang Wacana Anti Poligami”, dalam Jurnal Wacana, Vol 10, No 1 April.

Yunus, Mahmud, (1996). Hukum Perkawinan dalam Islam menurut Mazhab Syafi'i, Hanafi, Maliki, dan Hambali, Jakarta: PT. Hidakarya Agung.

Zuhdi, Masjfuk, Masail Fiqhiyyah. (1989). Jakarta: CV. Haji Masagung.

Zulfikar, et. al. (2020). The Da'wah Movement of Ulama Dayah (Analysis the Da'wah Movement of Têungkū Hasanoel Bashry). Britain International of Humanities and Social Sciences (BIoHS) Journal, 2(1), 90-99.

\section{Interview list}

Achyar Nst, Tokoh NU Kota Medan, wawancara pada hari Selasa, 10 Februari 2016. Jam 14. $00 \mathrm{Wib}$

M. Abror Daud Faza, Pengurus NU Kota Medan, wawancara pada hari Selasa, 9 Februari 2016. Jam 10. $00 \mathrm{Wib}$.

Ngatman Azis, Tokoh NU Kota Medan, wawancara pada hari Selasa, 9 Februari 2016. Jam 14. $00 \mathrm{Wib}$.

Prof Dr syukur kholil M.A, tokoh NU Kota Medan, wawancara pada hari rabu, 10 Februari 2016 Jam $10.30 \mathrm{Wib}$

Prof Dr Katimin, M.Ag, Tokoh NU Kota Medan, wawancara pada hari kamis 11 Februari 2016 Jam 10.30 Wib

Prof. Dr.Pagar Hasibuan, M.A,Tokoh NU Kota Medan, wawancara pada hari kamis 11 Februari 2016 Jam 14.00 Wib

Dr.Nasrun Jami'Daulay, M.A, Tokoh NU Kota Medan wawancara pada hari selasa, 9 Februari 2016. Jam 16. $00 \mathrm{Wib}$

Dr.Pangeran Harahap, M.Ag,Tokoh NU Kota Medan selasa 9 Februari 2016, Jam 1100 Wib 